\title{
About the identity of Granulina pusaterii Smriglio \& Mariottini, 2003 (Volutoidea: Granulinidae) from the Tunisian Plateau
}

\author{
Franck Boyer ${ }^{1 *}$ - Walter Renda ${ }^{2} \bullet$ Attilio Pagli $^{3}$ \\ 1 Garrigues-Sainte-Eulalie, Gard, France \\ ${ }^{2}$ Amantea, Calabria, Italy \\ ${ }^{3}$ Empoli, Toscana, Italy
}

https://orcid.org/0000-0003-4162-2124

(D) https://orcid.org/0000-0003-3944-6758

(D) https://orcid.org/0000-0002-2581-0291

Boyer, F., Renda, W. \& Pagli, A. (2021). About the identity of Granulina pusaterii Smriglio \& Mariottini, 2003 (Volutoidea: Granulinidae) from the Tunisian Plateau. Ege Journal of Fisheries and Aquatic Sciences, 38(4), 461-466. DOI:10.12714/egejfas.38.4.07

Abstract: On the ground of an extensive study of topotypes and of the shell morphology documented in comparable Mediterranean populations, Granulina pusaterii Smriglio \& Mariottini, 2003 described from the Tunisian Plateau is proved to belong to the natural variability of G. melitensis Smriglio, Mariottini \& Rufini, 1998 and it is proposed as junior synonym name of the latter.

Keywords: Granulinidae, Granulina, Mediterranean Sea, shell morphology, variability, synonymy

\section{INTRODUCTION}

Since the pioneering work of Gofas (1992), several new species of Granulina were described from the Mediterranean waters by various authors, most from circalittoral or upper bathyal levels, and a supraspecific revision of the granuliniform gastropods was proposed by Boyer (2017). More recently, few works were dedicated to the phenetic variability occurring in some Granulina species from Mediterranean, and partial specific revisions were proposed (Boyer et al., 2017 and Boyer et al., 2020). In most cases, an extensive documentation about the chromatism of the soft parts remains to be gathered for conclusive revisions. In some occurrences, it seems however that the shell morphology data allow by themselves to reach robust conclusions, if based on a representative material.

This consideration leads to dedicate the present article to a shell morphology-based revision of the taxon G. pusaterii Smriglio and Mariottini (2003) only reported from its type locality on the border of the Tunisian Plateau and never revised since its description. The identity of $G$. pusaterii has been originally defined by comparison with $G$. melitensis Smriglio et al.(1998), described from Malta, so the present work will proceed as a comparison between these two taxa, referring both to the morphologic variability displayed by a lot of topotypes of $G$. pusaterii recently discovered in the collection of Attilio Pagli, and to the morphologic variability of $G$. melitensis extensively pictured by Boyer et al. (2020) in their recent revision of the granulinid fauna from the coasts of Turkey.

\section{MATERIAL AND METHODS}

The documentation of this work is based on the variability of G. melitensis as documented by Boyer et al. (2020) in the frame of their study of the Granulina fauna from the waters of Turkey, and on an important lot of topotypes of G. pusaterii studied more recently by the authors. This lot of 181 topotypes constitutes the main part of a sampling of 201 similar shells sorted out of from shell grit dredged at $100 \mathrm{~m}$ on the Tunisian Plateau, 60 miles off Sfax, and saved by Dr Marco Taviani: 20 shells were selected firstly by Carlo Smriglio and Paolo Mariottini, as type material of their new species G. pusaterii, and the 181 remaining shells were sorted out later from grit of the same sample by the third author without conclusive identification.

The holotypes of G. melitensis and of G. pusaterii have been studied on the ground of new photos performed at higher resolution by Antonio Bonfitto (Museo di Zoologia di Bologna).

For the presentation of the morphologic variability in the nominal G. melitensis, the reader will refer to the extensive iconography given in Boyer et al. (2020) (Figures 6A-P, 10A, 10C-D, 10P, 11D, 11M-P), whereas the morphologic variability at work in the taxon $G$. pusaterii is illustrated herein through six contrasted topotypes (Figures 1G-I; 2A-I). The tentative of making morphometric graphics of this multifactorial variability range proved to be not operative neither probative in the present case, and the direct comparison of referred pictures 
looks to give more valuable information than any superposition of scatter graphs.

\section{Abbreviations and Acronyms}

BEL: Benthic Ecology Laboratory, University of Messina. ISMAR : Istituto di Scienze Marine, Bologna.

MZB : Museo di Zoologia di Bologna.

APC : Attilio Pagli Collection.

FBC : Franck Boyer Collection.

WRC : Walter Renda Collection.

spm : specimen.

$L$ : length.

$\mathrm{lb}$ : ibidem, like the previous bibliographic reference.

e. g.: "exempli gratia", for instance.

\section{RESULTS}

In the present study, Granulina pusaterii Smriglio \& Mariottini, 2003 and G. melitensis Smriglio, Mariottini \& Rufini, 1998 have been compared for their shell morphology on the ground of their respective type material, of topotypes of $G$. pusateri, and of extensive samples of $G$. melitensis previously studied by Boyer et al. (2020). This morphologic comparison is evidencing that $G$. pusateri belongs to the natural variability of G. melitensis.

\section{Systematics}

Phylum: Mollusca

Class: Gastropoda

Order: Neogastropoda

Superfamily: Volutoidea Rafinesque, 1815

Family: Granulinidae Coovert \& Coovert, 1995

Genre: Granulina Jousseaume, 1888

Type-species: Marginella pygmaea Issel, 1869 (nonMarginella pygmaea Sowerby, 1846) = Marginella isselli Nevill and Nevill, 1875 (nom. nov.). By monotypy.

Granulina melitensis (Smriglio et al., 1998) (Figure 1, A-C). Smriglio et al. (1998) (pp. 53-56, figures 1-7)

\section{Type material}

Holotype MZB (Figure 1, A-C), L= $2.2 \mathrm{~mm}$, and 11 paratypes in the collections Smriglio, Mariottini, Ruffini and Engl.

\section{Other material examined} (2020):
APC: 181 spm, 60 miles off Sfax, 100m.

FBC: typical form = $1 \mathrm{spm}$, Anzio, Coste Laziali, $250 \mathrm{~m}$; large angular form = 11 spm, Capri Island, 200 m; 4 spm, Karpathos Island, no depth datum.

WRC: thick inflated form $=5 \mathrm{spm}$, Egadi Islands, $500 \mathrm{~m}$.

BEL: $11 \mathrm{spm}$, Eolie Islands, $300 \mathrm{~m}$.

The species was originally described by Smriglio et al. (1998: 53-54): « Specie di piccola taglia, l'olotipo misura $2.2 x$ $1.4 \mathrm{~mm}$, di forma ovoidale allungata anteriormente, con l'ultima spira avvolgente tutto l'insieme dei giri precedenti, che presenta una rottura del profilo anteriore accentuata. Rostrazione pronunciata e posta centralmente rispetto l'asse de avvolgimento del nicchio; apertura boccale stretta ed allungata, labro ispessito che internamente presenta una serie di denticolazioni fitte e poco rilevate. La parete labiale esterna, osservata lateralmente si presenta notevolmente inspessita, quasi callosa, e nella parte terminale posteriore si arcua allindietro verso il dorso del nicchio. La columella presenta quattro pliche che si raddopiano all'interno dell'apertura, e sono separate da una depressione, poco visibile, posta longitudinalmente. Superficie del nicchio liscia, lucida e brillante; colorazione bianco lattea, lievemente trasparente nelle conchiglie fresche. Le dimenzioni medie di G. melitensis, calcolate dopo la misurazione di tutto il materiale tipico, sono pari a $2.1 \times 1.4 \mathrm{~mm}$, il rapporto $H / D$ é pari a 1.49 ».

\section{Type locality}

Malta, 100-120 m.

\section{Distribution}

Documented from the northern Alboran Sea, the Tyrrhenian Sea, the Ionian Sea, Malta, the Gulf of Gabès, the Aegean Sea and the Turkish Levantine and Aegean coasts.

\section{Remarks}

Boyer et al. (2020) reported that the shell of Granulina melitensis seems to present a morphologic cline in Western Mediterranean, with transitional forms getting closer to the thick and rounded G. minusculina (Locard, 1897) in the Alboran Sea and parts of the Tyrrhenian (e.g.: Eolie Islands, $300 \mathrm{~m}$ and Egadi Islands, $500 \mathrm{~m}$ ). Other distinctive variants are occurring in the Tyrrhenian, like a large angular form observed off Capri Island at $200 \mathrm{~m}$, as well as various intergrades linking these variants to the typical form of $G$. melitensis.

In the Eastern Mediterranean Basin, the shell morphology of $G$. melitensis looks as less contrasted, even if a noticeable variability in observed in geographical populations, as demonstrated by Boyer et al. (2020) about the Turkish waters. 
In their description article, Smriglio et al. (1998) are underlining the originality of the apical labrum morphology, looking as bending backwards when viewed laterally [Smriglio et al. (1998, 54), Description: " The top of the posterior end of the outer lip is bending towards the dorsum of the shell'], what is considered by them as a distinctive specific feature at the scale of the Mediterranean fauna (ib., Discussion : "character unmistakable for the identification of the species").

Granulina pusaterii Smriglio and Mariottini (2003) (Figure 1, D-I and Figure 2, A-I).Smriglio and Mariottini (2003) (pp. 286-288, figures 737a-740b).

\section{Type material.}

Holotype MZB-14683 (Figure 1, D-F), L = $1.8 \mathrm{~mm}$, and 19 paratypes in the collections Smriglio and Mariottini (2003).

\section{Other material examined}

APC : 181 spm, 60 miles off Sfax, 100 m (topotypes).

\section{Original description}

Smriglio and Marriottini (2003: 286): «Species small (holotype: $1.8(H) \times 1.3(D) \mathrm{mm}$ ), ovoid in shape slightly pyriform, last whorl enclosing all the previous whorls, a break in the anterior profile just traced. Posterior rostration weak, anterior rostration slightly elongated, semi-central with respect to the columellar axis. Aperture narrow; outer labial varix not too thick, showing interiorly a series of small teeth, few, inequal and weak. Four strong columellar plicae. Surface of the shell smooth and bright. Colour milky white, slightly translucent even in fresh specimens. No microsculpture evident even at strong magnification ».

\section{Type locality}

60 miles off Sfax, $100 \mathrm{~m}$.

\section{Distribution}

Only referred from the type locality.

\section{Remarks}

The name Granulina pusaterii is attributed by Smriglio and Mariottini (2003) to a phenon said to be « similar to Granulina melitensis Smriglio, Mariottini and Rufini, 1998, from which (it) differs by the presence of strong diagnostic characters, as follows:

1. smaller average size $(1.8 \times 1.3 \mathrm{~mm})$ instead of $2.1 \times 1.4$ $\mathrm{mm}$ in G. melitensis,

2. general shape more inflated and less slender (H/D ratio=1.38), G. melitensis $=1.49$,

3. labial teeth smaller and more irregularly spaced,

4. stronger and more evident columellar plicae.

\section{DISCUSSION}

The type material of $G$. pusaterii is made of 20 specimens sorted out from a set of 201 similar shells matching closely the typical form of $G$. melitensis. The holotype of $G$. pusaterii (Figures 1D-F) looks as slightly diverging from the typical form of $G$. melitensis (Figures $1 \mathrm{~A}-\mathrm{C}$ ) by its less pyriform and more oval outline, and by its less produced upper rostrum. Paratypes A and D selected by Smriglio and Mariottini (2003: figures 238a-b and 240a-b) are more oval-shaped, whereas paratype $B$ (ib: figures 239a-b) is matching more closely the typical form of $G$. melitensis, despite a less sharp upper rostrum. The type material selected by Smriglio and Mariottini (2003) as representative of their new taxon G. pusaterii looks as corresponding to the 20 most « oval-shaped shells " among a series of 201 specimens belonging to the variability range of $G$. melitensis, even if this Tunisian population is showing to be less strongly rostrated in its whole than the holotype of $G$. melitensis (Figure 1, G-I and Figure 2, A-I). We note that various topotypes of $G$. pusaterii are intergrading between the oval and low-rostrated specimens selected in the type series of G. pusaterii and the typical form of G. melitensis: the holotype of G. pusaterii (Figure 1, D-F) is for instance matching closely the topotype illustrated in Figure 2, D-G and the three paratypes of $G$. pusaterii pictured in Smriglio and Mariottini (2003) (ib.) are closely matching the topotype illustrated in Figure 2, F-I.

On the ground of the variability observed in the population from the type locality of $G$. pusaterii, the comparison made by Smriglio and Mariottini (2003) between the « more oval shaped » G. pusaterii and the « more pyriform » G. melitensis must be corrected:

1. The specimens selected as type material of $G$. pusaterii are ranging from $1.7 \mathrm{~mm}$ to $2.0 \mathrm{~mm}$, versus $1.8 \mathrm{~mm}$ to $2.1 \mathrm{~mm}$ for the 181 topotypes, whereas the type material of $G$. melitensis is sizing $1.8 \mathrm{~mm}$ to $2.2 \mathrm{~mm}$. So the phenon G. pusaterii cannot be distinguished on the simple ground of its length size. We note that the diversified populations of $G$. melitensis observed from the coasts of Turkey are sizing $1.9 \mathrm{~mm}$ to $2.35 \mathrm{~mm}$, that means a bit larger than the type material from Malta and the population studied from the Tunisian Plateau.

2. The more rounded and squatter look of $G$. pusaterii is just coming from the fact that the authors did select the specimens presenting the lowest rostrum. As a result, their length size is also shorter. Such "low rostrated " and "poorly pyriform » shells belong to the natural variability of $G$. melitensis, as demonstrated by Boyer et al. (2020) about the populations studied from the coasts of Turkey. In fact, all the intergrades are represented among the topotypes of $G$. pusaterii, from rather oval outline (Figure $2 \mathrm{C}$ ) to strongly rostrated (Figure 1, G-I) and to heavily pyriform (Figure 2, E- H).

3. Tiny and irregularly spaced labial teeth are also found in more rostrated shells (Figure $2 \mathrm{C}$ ), as well as quite smooth inner labrum (Figure 2, E-F). The size, number and distribution of the labial teeth prove to be deeply variable in $\mathrm{G}$. melitensis (Boyer et al., 2020). 
4. Strong and produced columellar plaits are also found in rostrated and pyriform shells (Figure 1, G-I). The position and the orientation of the columellar plaits show to be rather constant in G. melitensis, but their thickness and their elevation show to be noticeably variable (Boyer et al., 2020).
And last, we must notice that the holotype of $G$. pusaterii (Figure 1, D-F) as well as its topotypes (Figure 1, G-I) are all showing their apical labrum bending backwards, what was considered by the describers themselves as a specific feature characterizing G. melitensis, when they described this species (see above).

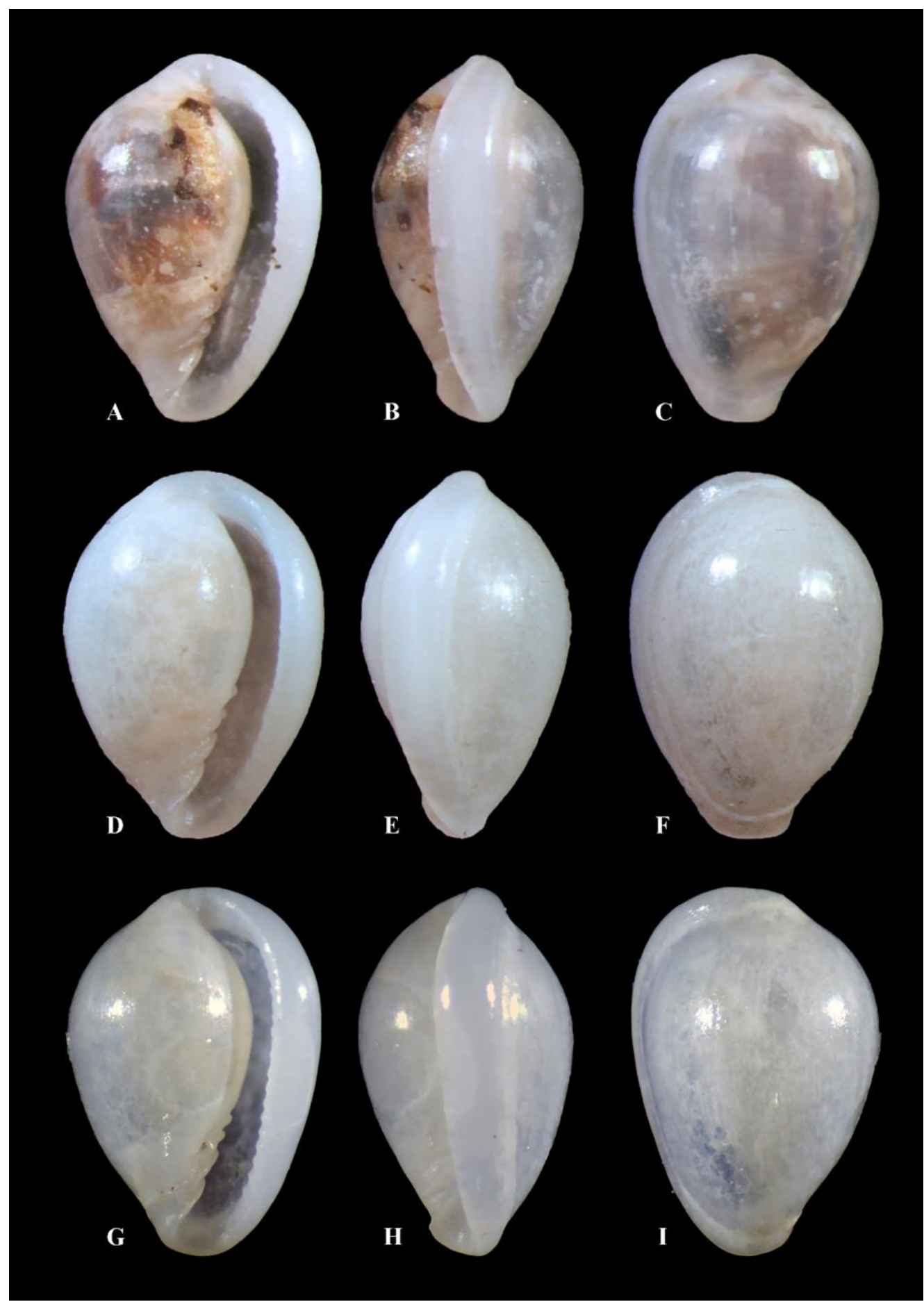

Figure 1. A-I. A-C. Granulina melitensis, holotype MZB, Malta, 100-120m, L = $2.2 \mathrm{~mm}$.

D-F. G. pusateri, holotype MZB, off Sfax, $100 \mathrm{~m}, \mathrm{~L}=1.8 \mathrm{~mm}$. G-I. G. melitensis, off Sfax, $100 \mathrm{~m}, \mathrm{~L}=2.0 \mathrm{~mm}$, APC. 


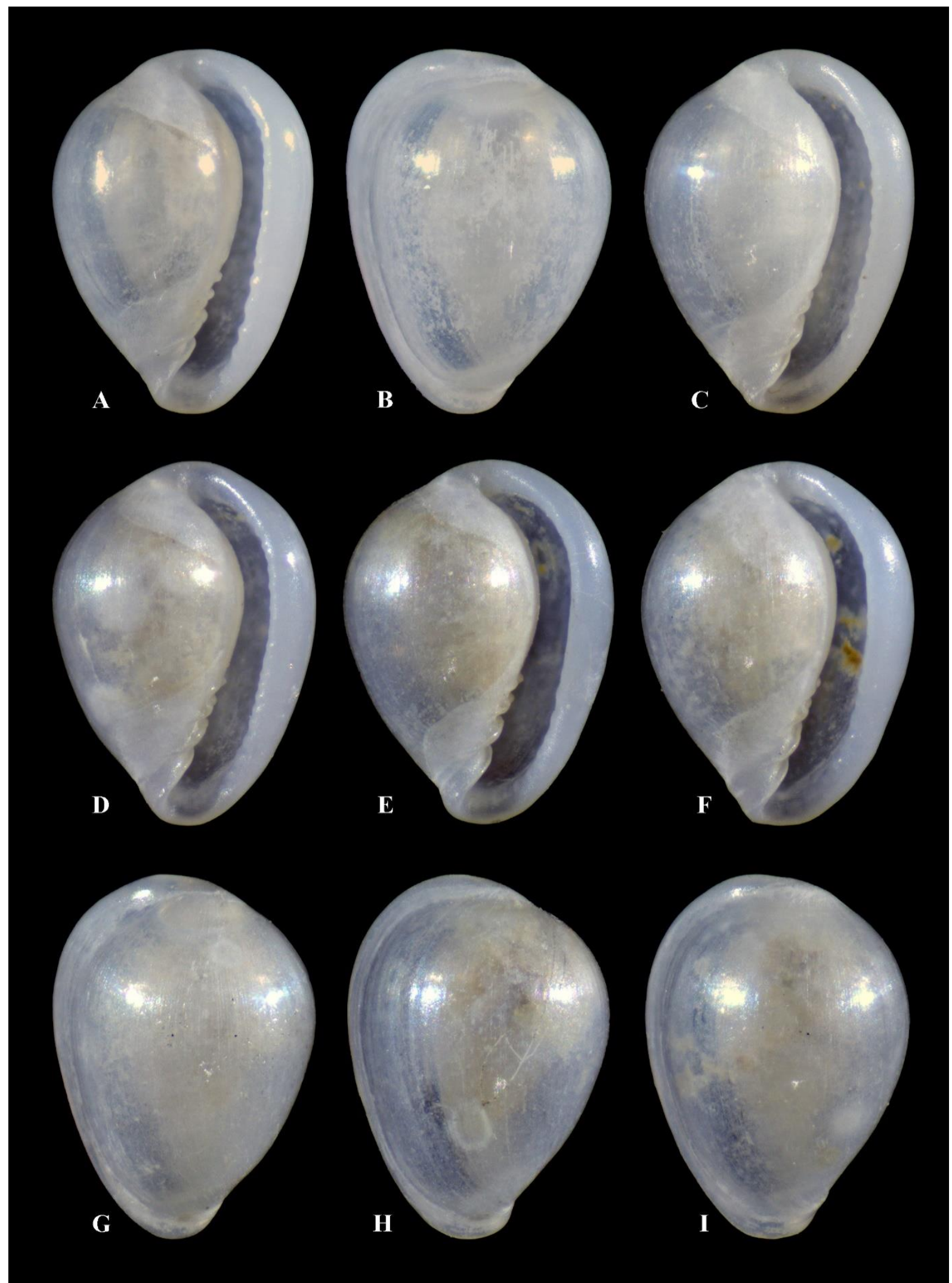

Figure 2. A-I. A-B. Granulina melitensis, off $S f a x, 100 \mathrm{~m}, \mathrm{~L}=2.1 \mathrm{~mm}$. C. idem, $\mathrm{L}=2.0 \mathrm{~mm}$. D-G. idem, $\mathrm{L}=2.0 \mathrm{~mm}$. E-H. idem $\mathrm{L}=2.0 \mathrm{~mm}$. F-I. idem, $L=1.8 \mathrm{~mm}$. All from APC. 


\section{CONCLUSION}

On the ground of the shell morphology studied on a diversified material from its type locality (type material and topotypes), G. pusaterii shows to belong to the natural variability of the species $G$. melitensis and it must be considered as junior synonym name. In its whole, the population studied from the Tunisian Plateau looks to have slightly smaller and less rostrated shells than the typical population from Malta and the populations studied from the coasts of Turkey (Boyer et al., 2020). The higher disparities observed in the populations from Turkey is possibly coming from the wide dispersion of the numerous documented stations

\section{REFERENCES}

Boyer, F. (2017). Révision de l'organisation supra-spécifique des gastéropodes granuliniformes. Xenophora Taxonomy, 16, 25-38.

Boyer, F., Renda, W., Bogi, C. \& Giacobbe, S. (2017). About an assemblage of Granulina species from South-eastern Tyrrhenian Sea and close Messina Strait (Central Mediterranean). Bollettino Malacologico, 53(1), $1-8$.

Boyer, F., Renda, W. \& Öztürk, B. (2020). The genus Granulina (Mollusca: Gastropoda: Neogastropoda) from the Turkish coasts with taxonomical notes on some Mediterranean species. Ege Journal of Fisheries and Aquatic Sciences, 37 (1), 65-83

DOI: 10.12714/egejfas.37.1.09 and from the diversified depths of the stations at infralittoral and circalittoral levels.

\section{ACKNOWLEDGEMENTS}

Thanks are due to Dr Marco Taviani (ISMAR) for the access to the shell grit sampled from the Tunisian Plateau. We are also greatly indebted to $\operatorname{Pr}$ Antonio Bonfitto (MZB) who performed sharp photos of the holotypes of $G$. melitensis and of $G$. pusateri, and to Prof. Salvatore Giacobbe (BEL) for the loan of specimens from the Aeolian Islands. We are also indebted to Prof. Dr. Bilal Öztürk (EGE University, Izmir) for adjusting the form of the manuscript and for his constant help.

Gofas, S. (1992). Le genre Granulina (Marginellidae) en Méditerranée et dans l'Atlantique oriental. Bollettino Malacologico, 28 (1-4), 1-26.

Smriglio C., Mariottini P. \& Rufini S. (1998). Descrizione di Granulina melitensis n. sp. (Neogastropoda, Cystiscidae) per il Mar Mediterraneo. La Conchiglia, 287, 53-56.

Smriglio C. \& Mariottini P. (2003). Descrizione di Granulina pusaterii n. sp. (Cystiscidae Simpson, 1865) per il Mar Mediterraneo. In Giannuzzi-Savelli R., Pusateri F., Palmeri A. \& Ebreo C. (Eds), Atlante delle conchiglie marine del Mediterraneo, vol. 4 (Neogastropoda: Muricoidea) ( pp 286288). Evolver, Roma. 